\title{
O ENSINO DOS PRETÉRITOS A APRENDIZES BRASILEIROS DE ESPANHOL COMO LÍNGUA ESTRANGEIRA SOB O VIÉS DA TRADUÇÃO FUNCIONALISTA
}

\author{
THE TEACHING OF PAST TENSES TO BRAZILIAN LEARNERS OF SPANISH AS \\ A FOREIGN LANGUAGE WITH A BIAS TOWARDS FUNCTIONALIST \\ TRANSLATION
}

\author{
(a) \\ Valdecy de Oliveira PONTES \\ Universidade Federal do Ceará ${ }^{1}$ \\ Denísia Kênia Feliciano DUARTE² \\ Universidade Federal do Ceará
}

\begin{abstract}
Resumo: No contexto de tradução e ensino de línguas estrangeiras, alguns estudos têm tido resultados positivos ao unir atividades de tradução com a prática de sequências didáticas (SD) com gêneros textuais autênticos (BARRIENTOS, 2014; DEMÉTRIO, 2014; LAIÑO, 2014; PEREIRA, 2016; PONTES, BRASIL E PEREIRA, 2016; DUARTE, 2017). Neste artigo, objetivamos analisar as contribuições do uso da tradução funcionalista no ensino do Pretérito Perfeito Simples (PPS) e do Pretérito Perfeito Composto (PPC) para aprendizes brasileiros de língua espanhola. Portanto, examinamos os condicionamentos linguísticos e extralinguísticos nos usos desses tempos verbais em espanhol e em português, considerando o fenômeno de variação linguística; e verificamos como o uso da tradução pode contribuir para o ensino da variação linguística dos PPS e PPC do espanhol. Baseamo-nos em fundamentos teóricos da Tradução Funcionalista (NORD, 1994,2009, 2012), Tradução e Sociolinguística (BOLAÑOS-CUELLAR, 2000; MAYORAL, 1998), elaboração de SD (CRISTÓVÃO, 2010; BARROS, 2012) e pesquisas sobre a variação nas formas dos pretéritos do espanhol e português (PONTES (2009), OLIVEIRA (2007, 2010), BARBOSA (2008), DIAS (2004), etc.
\end{abstract}

Palavras-chave: Tradução Funcionalista. Pretérito Perfeito. Variação Linguística. Ensino de Espanhol.

\begin{abstract}
Within the context of translation and foreign language teaching, some studies have had positive results by joining translation activities with the practice of didactic sequences with authentic text genres (BARRIENTOS, 2014; DEMÉTRIO, 2014; LAIÑO, 2014; PEREIRA, 2016; PONTES, BRASIL AND PEREIRA, 2016; DUARTE, 2017).This paper aims to analyze the contributions of the functionalist translation uses in the teaching of "Pretérito Perfecto Simple" (PPS) and "Pretérito Perfecto Compuesto" (PPC) for Brazilian learners of Spanish. Therefore, the paper examines the linguistic and extralinguistic conditioning in the uses of these verb tenses in Portuguese and Spanish considering the phenomenon of linguistic variation to verify how the functionalist translation can contribute to the teaching of the linguistic variation of Spanish PPS and PPC tenses. This article was based on the theoretical foundations of Functionalist Translation (NORD, 1994, 2009, 2012), Translation and Sociolinguistics (BOLAÑOS-CUELLAR, 2000, MAYORAL, 1998), elaboration of SD (CRISTÓVÃO, 2010, BARROS, 2012) and research on the variation in the forms of preteritions of Spanish and Portuguese (PONTES (2009),OLIVEIRA (2007, 2010), BARBOSA (2008), DIAS (2004) AND OTHERS).

Keywords: Functionalist Translation. Linguistic variation. Past Perfect. Spanish Teaching.
\end{abstract}

RECEBIDO EM: 30/08/2017

ACEITO EM: 23/02/2018

PUBLICADO EM: julho de 2018

PONTES; DUARTE. O ensino dos pretéritos a aprendizes brasileiros de espanhol como língua estrangeira sob $o$ viés da tradução funcionalista

Belas Infiéis, v. 7, n. 1, p. 201-227, 2018. 


\section{Introdução}

$\mathrm{O}$

presente trabalho não tem a pretensão de defender uma perspectiva de ensino da língua espanhola associada apenas ao uso da tradução. Porém, ponderamos que a tradução pode ser utilizada como recurso didático no ensino de língua estrangeira. Branco (2009) assevera que a tradução deve ser vista como uma atividade facilitadora no ensino de Língua Estrangeira (LE) e não como uma simples interferência negativa da língua materna (LM). Desse modo, reiteramos que, ao conduzir o aluno a confrontar duas línguas, por meio da tradução, possibilitamos uma reflexão sobre o funcionamento de ambas as línguas e fomentamos uma análise linguística, no que diz respeito aos efeitos de sentido produzidos pelos pretéritos sob análise.

O objetivo geral que norteia o presente estudo é o de analisar as contribuições do uso da tradução no ensino do PPS (Pretérito Perfeito Simples) e do PPC (Pretérito Perfeito Composto) a aprendizes brasileiros de língua espanhola. Embora nossa pesquisa foque em uma análise linguística, por tratar de tempos verbais, acreditamos que a compreensão dos usos do pretérito perfeito simples e do composto, de forma contextualizada e contrastiva, contribuirá positivamente no processo comunicativo dos aprendizes, já que eles estarão aprimorando os seus conhecimentos tanto na LE quanto na LM.

\section{A tradução funcionalista e a abordagem dos pretéritos (PPS e PPC) em espanhol}

Embora haja uma proximidade entre o espanhol e o português, por serem línguas originadas do latim, há uma série de dificuldades enfrentadas na aprendizagem dessa língua por parte de estudantes brasileiros. Entre elas, destacamos a aprendizagem do Pretérito Perfeito Simples e Composto, pois devido à semelhança entre essas línguas, os estudantes brasileiros de Espanhol como Língua Estrangeira tendem a associar os usos e valores desses tempos verbais do português para o espanhol. Desta forma, julgamos que a tradução, a partir da perspectiva funcionalista, poderia ser um recurso pedagógico capaz de mostrar a estes aprendizes as semelhanças e diferenças existentes entre esses tempos verbais.

À vista disso, salientamos que na medida em que usamos a língua materna para o ensino da língua estrangeira, a partir da tradução, propiciamos aos alunos o conhecimento das diferenças entre as duas línguas, tanto do ponto linguístico quanto cultural. Desta forma, a tradução pode ser vista como um recurso didático capaz de mostrar que não existe correspondência um a um entre as línguas, por conta do contexto comunicativo e da variação

$\overline{\text { PONTES; DUARTE. O ensino dos pretéritos a aprendizes brasileiros de espanhol como língua estrangeira sob }}$ o viés da tradução funcionalista

Belas Infiéis, v. 7, n. 1, p. 201-227, 2018. 
linguística. Neste viés, Mayoral (1998) explicita o interesse do tradutor na variação linguística relacionada ao contexto social e situacional. Pontes (2014) pontua que o uso da tradução como procedimento, sob o ponto de vista didático, é mais enriquecedor, quando analisamos todo o processo tradutório.

Na visão de Pontes (2014), não se devem interpretar apenas as estruturas lexicais e morfossintáticas no ato tradutório, mas é essencial que se considere a situação pragmáticodiscursiva do texto a ser traduzido. Desse modo, uma análise sociolinguística do texto, o qual pretende-se traduzir, pode vir a contribuir para a ampliação do conhecimento do contexto no qual este foi produzido. Como Travaglia (2013), acreditamos que não se traduz uma língua, mas textos (orais ou escritos), visto que "a tradução é a passagem de um texto original redigido numa língua de partida, para um texto redigido numa língua de chegada", conforme Moscowitz (1972 apud TRAVAGLIA, 2013, p.77).

Entendemos como texto, neste estudo, a concepção de Travaglia (2013, p. 78), que o define como "o resultado de uma intenção comunicativa que num dado momento, numa dada situação, num dado contexto, com um dado objetivo se concretizou verbalmente, se organizou sob a forma linguística". Segundo a autora, "para que um texto seja texto é preciso constituirse num todo significativo para quem o lê ou ouve. A intenção comunicativa é assim textualizada. A textualização é, então, essa 'colocação em texto' de uma intenção comunicativa” (TRAVAGLIA, 2013, p. 78, grifos do autor). Tendo em conta esta concepção, ao traduzir debruçamo-nos sobre textos com marcas sociolinguísticas. Para que o receptor compreenda o contexto situacional traduzido da língua de partida para a língua de chegada, a tradução deve adequar-se às especificidades e exigências da comunicação. Considerando que os eventos comunicativos então condicionados por fatores linguísticos e extralinguísticos, ao traduzir devemos atentar-nos às influências sociais, linguísticas e culturais, isto é, levar em conta os processos de variação e mudança linguísticas.

Como Bortoni-Ricardo (2006, p. 105), reiteramos que "estudar uma língua significa estudar os processos de comunicação da comunidade que a usa" e que a "linguagem só pode ser devidamente compreendida quando estudada no contexto do comportamento social”. Desta forma, o uso da tradução, sob uma perspectiva sociolinguística, vem a contribuir para o ensino da variação linguística, visto que "a sociolinguística parte de estudo da língua em seu contexto social, enfatizando-lhe os aspectos funcionais e interacionais" (Bortoni-Ricardo, 2006, p. 104). Considerando esta questão, o nosso intuito não é nos determos no ensino do PPS e do PPC,

PONTES; DUARTE. O ensino dos pretéritos a aprendizes brasileiros de espanhol como língua estrangeira sob o viés da tradução funcionalista

Belas Infiéis, v. 7, n. 1, p. 201-227, 2018. 
voltado apenas para a forma, mas conscientizar os aprendizes sobre os usos e valores desses tempos verbais em distintos contextos comunicativos.

É oportuno explicitar que o nosso trabalho está ancorado na visão da Tradução Funcionalista, proposta por Nord (1991, 2012), que vê a tradução como um ato comunicativo real. Para a autora, a tradução se situa em espaços culturais, nos quais os sentidos se constroem por meio de textos, sejam estes orais, escritos ou visuais, de acordo com as funções e os seus interlocutores. De acordo com a teoria de tradução funcionalista de Nord, o texto não se limita a passar apenas uma informação para o seu receptor. O texto tem a função de comunicar, a partir da intenção do emissor no momento da produção do texto inicial e do contexto em que se insere o receptor. Sendo assim, o funcionalismo nordiano preocupa-se tanto com o texto fonte quanto com o texto meta. Logo, dá-se importância em manter a intenção do autor do texto original, considerando também o receptor do texto traduzido, pois o crucial é que a tradução seja funcional. Nas palavras de Nord (2012, p.13, tradução nossa) ${ }^{3}$, a tradução é produzida em um contexto comunicativo, no qual se empregam elementos como o texto meta e o texto base. "Comparada com outros contextos comunicativos, a tradução se trata de um contexto 204 comunicativo específico pelo fato de haver duas culturas (e línguas) implicadas nele".

No que toca ao funcionalismo, de acordo com Reiss e Vermeer (1996), um ponto importante para a teoria da tradução diz respeito à importância atribuída às mudanças de valor pelas quais os textos e elementos textuais passam ao serem transferidos a outra cultura. Sendo assim, como Reiss e Vermeer (1996), ponderamos que, ao traduzir, devemos ser biculturais, ou seja, temos que conhecer tanto a cultura de partida quanto a de chegada, pois o valor de um acontecimento pode variar, quando traduzido a outra cultura. Corroborando Reiss e Vermeer (1996), consideramos que a tradução não se limita apenas a um processo linguístico, esta é um processo cultural, considerando que o ato de traduzir é uma ação humana, em outras palavras, está composta por intenções e propósitos. Segundo Nord (2012), se analisarmos um texto verificando apenas os aspectos linguísticos do texto base (TB), esta análise não será suficiente para tornar uma tradução funcional, já que é essencial ultrapassar a barreira linguística, isto é, considerar o contexto cultural no qual o texto foi produzido e o contexto cultural do público que receberá a tradução.

A seguir, explicitamos o modelo de análise textual pré-tradutório, proposto por Nord (2012), o qual foi utilizado para nortear a nossa versão da tradução de um fragmento do conto "!Diles que no me maten!":

$\overline{\text { PONTES; DUARTE. O ensino dos pretéritos a aprendizes brasileiros de espanhol como língua estrangeira sob }}$ $o$ viés da tradução funcionalista

Belas Infiéis, v. 7, n. 1, p. 201-227, 2018. 
Quadro 1 - Análise textual pré-tradutória.

\begin{tabular}{|c|c|c|c|}
\hline & $\begin{array}{c}\text { PERFIL DO TEXTO } \\
\text { B ASE }\end{array}$ & TRANSFERÊNCIA & $\begin{array}{l}\text { PERFIL DO TEXTO } \\
\text { META }\end{array}$ \\
\hline & \multicolumn{3}{|c|}{ A. FATORES EXTRALINGUÍSTICOS } \\
\hline \multicolumn{4}{|l|}{ EMISSOR } \\
\hline \multicolumn{4}{|l|}{ INTENÇÃO } \\
\hline \multicolumn{4}{|l|}{ RECEPTOR } \\
\hline \multicolumn{4}{|l|}{ MEIO } \\
\hline \multicolumn{4}{|l|}{ LUGAR } \\
\hline \multicolumn{4}{|l|}{ TEMPO } \\
\hline \multicolumn{4}{|l|}{ MOTIVO } \\
\hline \multicolumn{4}{|l|}{ FUNÇÃ̃ } \\
\hline & \multicolumn{3}{|c|}{ B. FATORES INTRALINGUÍSTICOS } \\
\hline \multicolumn{4}{|l|}{ TEMA } \\
\hline \multicolumn{4}{|l|}{ CONTEÚDO } \\
\hline \multicolumn{4}{|l|}{ PRESSUPOSIÇÕ̃ES } \\
\hline \multicolumn{4}{|l|}{ COMPOSIÇÃO } \\
\hline \multicolumn{4}{|l|}{$\begin{array}{l}\text { ELEMENTOS NÃO } \\
\text { VERBAIS }\end{array}$} \\
\hline \multicolumn{4}{|l|}{ LÉXICO } \\
\hline \multicolumn{4}{|l|}{ SINTÁXE } \\
\hline \multicolumn{4}{|l|}{ SUPRASEGMENTAIS } \\
\hline & \multicolumn{3}{|c|}{ C. EFEITO COMUNICATIVO } \\
\hline EFEITO & & & \\
\hline
\end{tabular}

Fonte: Nord (2012, p.155, tradução nossa).

Como podemos observar, tal modelo é composto por duas seções: (1) fatores extratextuais e (2) fatores intratextuais. De acordo com Nord (2012), os fatores da primeira seção englobam elementos como o produtor e o emissor do texto e suas intenções, o receptor, o meio no qual o texto é veiculado, o tempo e o local da comunicação, o motivo para a produção do texto e a função textual. Já os fatores, da segunda seção, englobam o estilo, o tema e o conteúdo do texto, as suas pressuposições, as hierarquias textuais, a macro e a microestrutura, os elementos não-verbais, o léxico, a estrutural frasal e a fonologia. Para Nord (2010), este modelo possibilita uma maior compreensão do texto base e a interpretação de sua mensagem, explica e relaciona as estruturas linguístico-textuais com o sistema e a norma da língua base, determina a função dos elementos textuais dentro de um contexto comunicativo e é uma base confiável para ajudar nas escolhas tradutórias.

Dado que nesta pesquisa trabalharemos com a tradução funcionalista, o conhecimento dos fatores linguísticos (intratextuais) e extralinguísticos (extratextuais) é fundamental para que a tradução venha a comunicar o que o autor havia planejado. Tendo em vista que traduziremos

PONTES; DUARTE. O ensino dos pretéritos a aprendizes brasileiros de espanhol como língua estrangeira sob o viés da tradução funcionalista

Belas Infiéis, v. 7, n. 1, p. 201-227, 2018. 
o gênero conto e conscientes de que não é uma tarefa fácil traduzir textos literários, ainda no tocante ao funcionalismo de Nord, conforme Laiño (2014), enfatizamos que a tradução não é estática, sendo assim, ao escrever o texto o autor sempre tem uma intenção, e esta deve ser considerada pelo tradutor, que determinará a redação do texto em relação ao conteúdo e a forma.

Nesta perspectiva, ao traduzir um texto, as escolhas tradutórias devem considerar a audiência para a qual se destina a tradução, para assim, contemplar a sua função comunicativa. Consideramos importante este ponto para o ato tradutório, pois, muitas vezes, o tradutor pode não ter conhecimento para qual público irá traduzir e acabar produzindo traduções que causam estranhamento para ele.

Com o propósito de contribuir para abordagem da variação do Pretérito Perfeito da língua espanhola por meio da tradução, buscamos o reconhecimento do conteúdo do gênero conto (características específicas), o qual será traduzido, apoiando-nos no modelo de análise pré-tradutório da Nord (2012) que, a nosso ver, permitirá uma tradução comunicativa. Nord (2010) previa, neste modelo de análise textual, uma direção para o exercício tradutório, com o propósito de esmiuçar o texto original e compreendê-lo em sua totalidade, por conseguinte, facilitando a sua tradução.

Neste sentido, no que diz respeito ao gênero como instrumento de ensino de línguas, na acepção de Rabardel (1995), para que a interação verbal ocorra de forma eficaz por intermédio do gênero, este deve ser apropriado pelo sujeito para que ele possa conduzir a atividade linguageira. De acordo com Bronckart (2001), a apropriação dos gêneros é um instrumento crucial de socialização, de possibilidade de inserção prática dos sujeitos nas atividades comunicativas humanas. É nesta perspectiva que propomos o uso do gênero conto como instrumento de ensino da língua espanhola, pois, como Nascimento e Saito (2005), consideramos o gênero, de modo geral, como um objeto de ensino e aprendizagem que não se limita a estruturas gramaticais, ou seja, que possibilita o desenvolvimento de práticas discursivas e relações instauradoras. Para Barros (2012, p. 70), ao dominar um gênero o indivíduo "não aprende apenas a reconhecer sua estrutura composicional ou seus elementos linguísticos mais regulares, aprende, sobretudo, a agir numa determinada situação verbal".

Em suma, escolhemos trabalhar com o Pretérito Perfeito do indicativo através de contos, pois a estruturação e a funcionalidade desse gênero literário apresenta uma gama de expressões linguísticas, como, por exemplo, o uso de marcadores temporais, o qual será um dos condicionamentos linguísticos utilizados na análise do presente estudo. Ademais, consideramos

PONTES; DUARTE. O ensino dos pretéritos a aprendizes brasileiros de espanhol como língua estrangeira sob $o$ viés da tradução funcionalista

Belas Infiéis, v. 7, n. 1, p. 201-227, 2018. 
que os usos e valores dos tempos verbais ajudam na interpretação dos textos, logo, conjecturamos que a função do Pretérito Perfeito tem grande importância no desencadear dos contos, visto que esse é predominante nas narrações.

Em relação aos usos e valores desses pretéritos, na concepção de Matte Bon (1995a), entre os tempos do passado da língua espanhola, o PPS é o mais marcado pela problemática temporal, pois está extremamente relacionado com o passado em relação ao momento da enunciação, e é utilizado para informar sobre fatos passados (contar os fatos em si, sem criar nenhuma perspectiva específica). O PPC, por sua vez, quando é empregado, não é do interesse do enunciador contar o fato ao que se refere, pois a ação passada pode constituir uma explicação da situação descrita no presente do indicativo ou continuar sendo relevante em dita situação.

No entanto, se pensarmos a partir de uma perspectiva linguística, a visão de Matte Bon (1995a) é questionável, visto que há estudos linguísticos que mostram que, dependendo da região dialetal, o falante pode optar pelo uso frequente da forma simples. Por exemplo, o estudo de Santos (2009) constatou que o PPS e o PPC do espanhol têm usos distintos em Madri, na Cidade do México e em Buenos Aires. No entanto, as três capitais apresentam o uso predominante do PPS. Já o estudo de Paixão (2011) afirma que o PPC apresenta grandes divergências de uso entre línguas românicas distintas e, ainda, entre variantes dialetais e sociais de uma mesma língua.

Na visão de Jara Yupanqui (2013), o PPC é uma forma verbal frequente tanto na língua espanhola quanto em outras línguas do mundo, porém pode desaparecer com o tempo ou continuar mudando. Tal instabilidade é constatada no estudo de Harris (1982), que distingue, de forma diacrônica, o valor do PPC nas línguas românicas em quatro etapas, sendo elas: 1) referência a estados presentes resultantes de ações passadas, nos quais não se incluíam situações passadas recentes ou não; 2) aquisição de relevância presente em contextos específicos; 3) marcação de ações passadas com relevância no presente; e 4) uso com funções desempenhadas pelo PPS.

Em contrapartida, para Barbosa (2003), o PPC do espanhol não caiu em desuso, mas passou a ser empregado com distintos usos. A autora associa estes usos ao do português brasileiro, que expressa aspectos iterativo e durativo, como mostra a sentença abaixo:

1. - ¿Has escrito a Fulano? - Eso lo hemos discutido muchas veces. (LOPE BLANCH, 1961, p.136)

PONTES; DUARTE. O ensino dos pretéritos a aprendizes brasileiros de espanhol como língua estrangeira sob $o$ viés da tradução funcionalista

Belas Infiéis, v. 7, n. 1, p. 201-227, 2018. 
Nota-se que há uma ideia de repetição por meio do adjunto muchas veces, além disso, subtende-se que a ação de discutir tem uma duração contínua. Ainda em relação ao valor do PPC no espanhol, o estudo de Paixão (2011) sobre o Pretérito Perfeito na variedade mexicana mostra que a forma composta tem o valor experiencial ou resultativo, isto é, tem relevância no presente. Conforme a autora, a princípio, este uso não era típico desta variedade, o que mostra que esta forma verbal foi utilizada em contextos distintos antigamente, instabilidade esta que corrobora a ideia do estudo de Harris (1982).

Por fim, em relação ao PPS e o PPC, elencamos alguns estudos sobre diversidade linguística inerente a esses tempos verbais no espanhol e as suas respectivas considerações, no quadro a seguir:

Quadro 2 - Estudos sobre a diversidade linguística do PP do espanhol.

\begin{tabular}{|c|c|}
\hline AUTOR & CONSIDERAÇÕES \\
\hline Penny (2004) & $\begin{array}{l}\text { A alternância entre as formas do PPS e do PPC foi objeto de atenção } \\
\text { antes mesmo da aparição da sociolinguística variacionista, visto que } \\
\text { gramáticos e dialetólogos já teciam reflexões a respeito dessa } \\
\text { alternância, pontuando as diferenças entre umas regiões e outras. } \\
\text { Além disso, a preferência por uma das duas formas, que atuam neste } \\
\text { sentido como uma espécie de marcador regional, levou alguns } \\
\text { linguistas a concluir que a oposição entre o PPS e o PPC parece } \\
\text { neutralizada em algumas variedades da língua espanhola. }\end{array}$ \\
\hline $\begin{array}{l}\text { Aleza Izquierdo e } \\
\text { Enguita } \quad \text { Utrilla } \\
\text { (2010) }\end{array}$ & $\begin{array}{l}\text { Ao contrário do que nos dizem grande parte dos materiais didáticos, } \\
\text { existe sim o uso do PPC na América, ainda que a forma simples seja } \\
\text { predominante. }\end{array}$ \\
\hline $\begin{array}{l}\text { Vidal de Battini } \\
(1964)\end{array}$ & $\begin{array}{l}\text { Na Argentina, o uso do PPC é dominante no noroeste do país. No } \\
\text { restante das regiões argentinas, há a alternância entre a forma } \\
\text { composta e a forma simples, porém, o uso do PPS prevalece. }\end{array}$ \\
\hline $\begin{array}{l}\text { Donni de Mirande } \\
\text { (1992) }\end{array}$ & $\begin{array}{l}\text { Exceto nas regiões do norte da Argentina, não se utiliza o PPC para } \\
\text { referir-se a um passado com conexão com o presente na língua oral. } \\
\text { Os falantes argentinos preferem usar o PPS em quase todo tipo de }\end{array}$ \\
\hline
\end{tabular}




\begin{tabular}{|c|c|}
\hline & $\begin{array}{l}\text { contexto. Além disso, ressalta que o PPC tem mais frequência no } \\
\text { nível culto formal. }\end{array}$ \\
\hline Oliveira (2010) & $\begin{array}{l}\text { Os complementos adverbiais pré-hodiernos (ayer, la semana } \\
\text { passada, etc.) favorecem o uso do PPS, enquanto que os hodiernos } \\
\text { (hoy, esta mañana, etc.) favorecem o PPC. Entretanto, é possível } \\
\text { encontrar, em contexto hodierno, a forma verbal simples. }\end{array}$ \\
\hline Oliveira (2007) & $\begin{array}{l}\text { Tanto em países hispano-americanos como na Espanha há o uso tanto } \\
\text { do PPS quanto do PPC, porém este ocorre de forma diferente. O } \\
\text { emprego do PPS é mais frequente em todo contexto hispânico. }\end{array}$ \\
\hline Alcaine (2007) & $\begin{array}{l}\text { Devido ao contato com o quéchua, falantes de variedades hispânicas } \\
\text { pertencentes ao âmbito andino selecionam o PPS para transmitir uma } \\
\text { experiência vivida e o PPC para referir-se a um fato não presenciado, } \\
\text { de que não se tem certeza, com cuja veracidade da informação o } \\
\text { indivíduo tampouco pretende comprometer-se. }\end{array}$ \\
\hline Yupanqui & $\begin{array}{l}\text { A partir do contraste da frequência relativa do PPS e do PPC na } \\
\text { variedade do espanhol da cidade de Lima (1989 e 2013) com a de } \\
\text { outras capitais da América latina, os dados mostram que Lima (1989) } \\
\text { tem um padrão mais distante do México e mais próximo do Chile e } \\
\text { da Colômbia. Em contrapartida, os dados de Lima (2013) } \\
\text { aproximam-se mais do México. }\end{array}$ \\
\hline Dias (2004) & $\begin{array}{l}\text { Sobre as formas do PPS e do PPC no espanhol mexicano, com base } \\
\text { em estudos anteriores, entende-se que a oposição entre esses tempos } \\
\text { verbais é aspectual. A forma simples expressa um valor perfectivo } \\
\text { pontual, enquanto a forma composta expressa uma ideia de aspecto } \\
\text { durativo ou reiterativo. Sendo assim, o PPC, na variedade mexicana, } \\
\text { induz a pensar que as ações acontecem no passado e permanecem no } \\
\text { presente. Ademais, baseando-se em Gutiérrez Araus (1997), é } \\
\text { possível comparar o uso da forma composta na variedade mexicana } \\
\text { com o da variedade espanhola, já que, em ambas, o uso do PPC pode } \\
\text { se referir a fenômenos passados que perduram no presente. }\end{array}$ \\
\hline
\end{tabular}

Elaboração: Valdecy de Oliveira Pontes e Denísia Kênia Feliciano Duarte

PONTES; DUARTE. O ensino dos pretéritos a aprendizes brasileiros de espanhol como língua estrangeira sob $o$ viés da tradução funcionalista

Belas Infiéis, v. 7, n. 1, p. 201-227, 2018. 
Desta forma, feitas as considerações teóricas e linguísticas que permeiam a natureza dos tempos verbais em estudo, apresentamos, na próxima seção, os procedimentos metodológicos que nortearam a realização desta pesquisa.

\section{Metodologia}

Classificamos o presente trabalho como pesquisa-ação, visto que, na visão de Engel (2000), a pesquisa-ação se caracteriza como autoavaliativa, por examinar as constantes modificações ao decorrer do processo e apresentar um feedback. Conforme Gil (2010), na pesquisa-ação, são adotadas, para a coleta de dados, diversas técnicas, dentre elas a ficha de sondagem e o questionário, os quais foram utilizados na nossa pesquisa. No entanto, nesse artigo, focamos apenas no contraste entre a tradução inicial e a final, com vistas à aprendizagem dos pretéritos em espanhol.

No que diz respeito ao modelo didático utilizado, elaboramos uma sequência didática $(\mathrm{SD})^{4}$, conforme Dolz, Noverraz e Scheneuwly (2004), a partir das dificuldades diagnosticadas na primeira tradução dos alunos. Essa SD foi realizada na disciplina "Introdução aos Estudos 210 da Tradução em Língua Espanhola" (2ºmestre), ofertada de forma optativa, pela coordenação do Curso em Letras Língua Espanhola e suas Literaturas, de uma universidade pública. A disciplina tinha a carga horária total de 32 horas, resultando em um encontro semanal de 2 horas, durante 16 semanas.

Por ser uma optativa, estudantes de outros semestres puderam se matricular na disciplina, mas para participar da pesquisa somente foram considerados: 1. Aprendizes brasileiros de língua espanhola, sem parentes de origem hispânica em primeiro grau; 2. Estudantes em nível A2 ${ }^{5}$ (segundo semestre do curso de graduação); 3. Estudantes de ambos os sexos, com o português brasileiro como LM; 4. Estudantes regularmente matriculados na disciplina; 5. Estudantes que concordaram, de livre e espontânea vontade, a participarem da pesquisa, assinando o Termo de Consentimento Livre e Esclarecido para os participantes da pesquisa, exigido pelo Comitê de Ética. Desse modo, foram excluídos da pesquisa os estudantes que não atendem a tais critérios.

$\mathrm{Na}$ apresentação da situação, para a produção inicial, consideramos: características do gênero conto; contextualização do conto “iDiles que no me maten!”, a partir da exibição de vídeos e leitura do fragmento (quadro 03), objeto da tradução. Pressupostos de Nord (2012)

PONTES; DUARTE. O ensino dos pretéritos a aprendizes brasileiros de espanhol como língua estrangeira sob o viés da tradução funcionalista

Belas Infiéis, v. 7, n. 1, p. 201-227, 2018. 
foram utilizados nesta fase com o intuito de mostrar a relevância do conhecimento prévio sobre o tema e o conteúdo do texto-fonte para uma tradução funcional.

A produção inicial, visando à aprendizagem cooperativa, foi realizada em cinco grupos de alunos. A partir do diagnóstico da produção inicial, propomos aos estudantes módulos referentes aos pretéritos, especificamente, no que diz respeito às dificuldades dos alunos em relação aos usos e valores dessas formas verbais. Na última etapa, para a produção da versão final, a expectativa era a da incorporação de fatores linguísticos e extralinguísticos considerados no decorrer dos módulos. Para cumprir com o encargo didático de tradução, proposto por Nord (2012), a última versão foi publicada em uma página do facebook, destinada à tradução de contos hispânicos, criada para esta pesquisa.

A escolha por alunos(as) matriculados(as) nessa disciplina resultou da aproximação temática dessa com os objetivos da pesquisa. Por ser uma disciplina optativa, estudantes de outros semestres puderam participar da disciplina, mas para a análise da pesquisa somente foram considerados os resultados de: 1. Aprendizes brasileiros de língua espanhola sem parentes de origem hispânica em primeiro grau; 2. Estudantes em nível básico (segundo semestre do curso de graduação); 3. Estudantes de ambos os sexos, com o português brasileiro como LM; 4. Estudantes regularmente matriculados na disciplina; 5. Estudantes que concordaram, de livre e espontânea vontade, em participar da pesquisa, assinando o Termo de Consentimento Livre e Esclarecido para os participantes da pesquisa, exigido pelo Comitê de Ética.

Em relação aos cinco grupos participantes da pesquisa (cada grupo foi composto por 4 alunos, considerando o total de alunos participantes), expomos que cada um deles recebeu o mesmo fragmento do conto “'Diles que no me maten!” do mexicano Juan Rulfo. Nessa fase, mostramos aos participantes a página de facebook "Contos Hispânicos", criada, pelos autores desta pesquisa, para leitores brasileiros de contos, e, em seguida, convidamos os alunos a publicarem as suas traduções do fragmento do conto para o português brasileiro. Para isso, primeiramente, indicamos qual seria o encargo de tradução, isto é, qual a função comunicativa das suas respectivas traduções.

Por se tratar apenas da tradução de um fragmento do texto, justificamos que este fator não prejudicou as escolhas tradutórias feitas pelos alunos, pois, em um momento anterior a esta etapa, foi feita a contextualização dos contos, por meio da leitura deste e da apresentação da história por meio de um curta-metragem. A escolha do fragmento a ser traduzido não foi feita

PONTES; DUARTE. O ensino dos pretéritos a aprendizes brasileiros de espanhol como língua estrangeira sob o viés da tradução funcionalista

Belas Infiéis, v. 7, n. 1, p. 201-227, 2018. 
de maneira aleatória. Para a escolha desse fragmento, consideramos os seguintes critérios: a) presença do pretérito perfeito simples e composto; b) situação em que o autor escolhe uma variante predominante do pretérito; c) presença de marcas temporais/aspectuais/modais. Optamos por um fragmento, pois o conto era extenso e poderia resultar complexa a sua tradução por parte dos alunos do segundo semestre (nível A2). Conforme Nord (2012, p. 160):

\begin{abstract}
Evidentemente, é difícil encontrar textos autênticos que não sejam muito extensos e que disponham do grau exato de dificuldade adequado para os alunos de um determinado nível. Mas, se um texto é muito longo ou muito difícil, a tarefa pode ser facilitada com um encargo específico, pedindo, por exemplo, uma tradução de apenas certas partes do texto, combinada com uma leitura superficial ou com um resumo na língua meta (que é, definitivamente, uma forma especial de tradução e que pode ser motivada pelo encargo). ${ }^{6}$
\end{abstract}

Vejamos o trecho selecionado:

Quadro 03 - Fragmento do conto !Diles que no me maten!, de Juan Rulfo

Luego, como queriendo decir algo, miraba a los hombres que iban junto a él. Iba a decirles que lo soltaran, que lo dejaran que se fuera: "Yo no le he hecho daño a nadie, muchachos", iba a decirles, pero se quedaba callado. "Más adelantito se los diré", pensaba. Y sólo los veía. Podía hasta imaginar que eran sus amigos; pero no quería hacerlo. No lo eran. No sabía quiénes eran. Los veía a su lado ladeándose y agachándose de vez en cuando para ver por dónde seguía el camino.

Los había visto por primera vez al pardear de la tarde, en esa hora desteñida en que todo parece chamuscado. Habían atravesado los surcos pisando la milpa tierna. Y él había bajado a eso: a decirles que allí estaba comenzando a crecer la milpa. Pero ellos no se detuvieron.

Los había visto con tiempo. Siempre tuvo la suerte de ver con tiempo todo. Pudo haberse escondido, caminar unas cuantas horas por el cerro mientras ellos se iban y después volver a bajar. Al fin y al cabo la milpa no se lograría de ningún modo. Ya era tiempo de que hubieran venido las aguas y las aguas no aparecían y la milpa comenzaba a marchitarse. No tardaría en estar seca del todo.

Así que ni valía la pena de haber bajado; haberse metido entre aquellos hombres como en un agujero, para ya no volver a salir.

Y ahora seguía junto a ellos, aguantándose las ganas de decirles que lo soltaran. No les veía la cara; sólo veía los bultos que se repegaban o se separaban de él. De manera que cuando se puso a hablar, no supo si lo habían oído. Dijo:

-Yo nunca le he hecho daño a nadie -eso dijo. Pero nada cambió. Ninguno de los bultos pareció darse cuenta. Las caras no se volvieron a verlo. Siguieron igual, como si hubieran venido dormidos.

Entonces pensó que no tenía nada más que decir, que tendría que buscar la esperanza en algún otro lado. Dejó caer otra vez los brazos y entró en las primeras casas del pueblo en medio de aquellos cuatro hombres oscurecidos por el color negro de la noche.

-Mi coronel, aquí está el hombre.

Se habían detenido delante del boquete de la puerta. Él, con el sombrero en la mano, por respeto, esperando ver salir a alguien. Pero sólo salió la voz:

-¿Cuál hombre? -preguntaron.

$\overline{\text { PONTES; DUARTE. O ensino dos pretéritos a aprendizes brasileiros de espanhol como língua estrangeira sob }}$ $o$ viés da tradução funcionalista

Belas Infiéis, v. 7, n. 1, p. 201-227, 2018. 


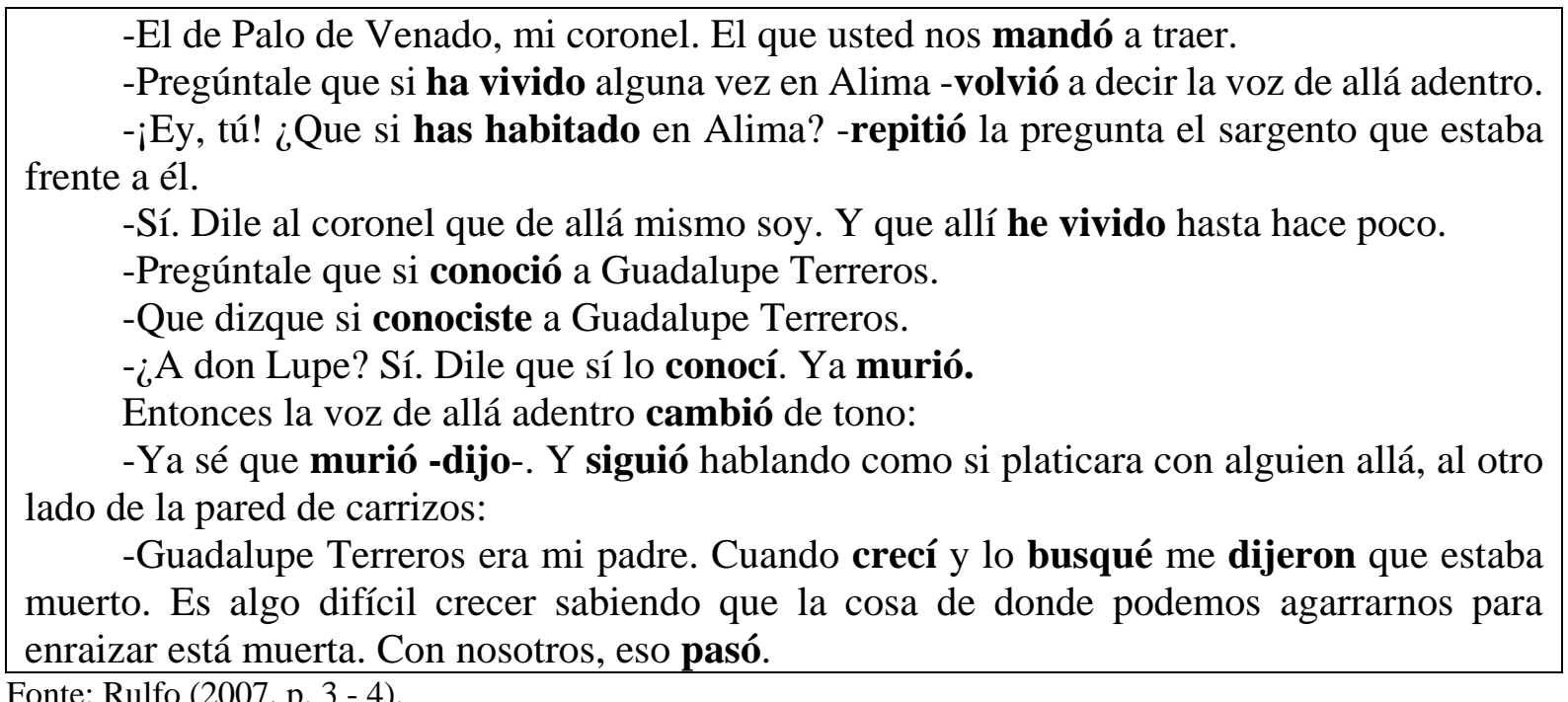
Fonte: Rulfo (2007, p. 3 - 4).

Os alunos realizaram as traduções e os módulos da sequência didática em sala de aula, sob a supervisão dos pesquisadores. Para isso, puderam consultar dicionários, gramáticas, google e outras fontes da internet. Após a tradução inicial, foram feitos módulos que ajudassem os alunos a melhorar sua tradução final. Baseando-nos em Barros (2012) e Dolz, Noverraz e Schneuwly (2004), elaboramos a quantidade de módulos realizados na nossa SD, considerando as necessidades dos alunos, as quais foram diagnosticadas por meio da produção inicial e também no decorrer do desenvolvimento dos módulos. Então, elaboramos dez módulos, nos quais três foram realizados antes da primeira tradução (módulos de reconhecimento, conforme COSTA HÜRBES e SIMIONE (2014)). Já os outros sete foram realizados no intervalo entre a $1^{\text {a e a }} 2^{\text {a }}$ tradução. Salientamos que em cada módulo buscamos integrar as três capacidades de linguagem ${ }^{7}$ utilizadas pela escola de Genebra no desenho da SD. Porém, tendo em vista o foco deste estudo, a variação do Pretérito Perfeito no espanhol, grande parte dos módulos contemplou as capacidades linguístico-discursivas.

A seguir, pontuamos os objetivos de cada módulo proposto: Quadro 04 - Objetivos dos módulos da SD e as capacidades de linguagem envolvidas

\begin{tabular}{|c|l|l|}
\hline MÓDULOS & \multicolumn{1}{|c|}{ OBJETIVOS PROPOSTOS } & $\begin{array}{l}\text { CAPACIDADES DE } \\
\text { LINGUAGEM }\end{array}$ \\
\hline \multirow{3}{*}{ M1 } & $\begin{array}{l}\text { - Apresentar as principais características do gênero } \\
\text { conto, por meio dos da apresentação de dois } \\
\text { contos, um de Jorge Luis Borges } \\
\text { e o outro de Julio Cortázar, e questionamentos em } \\
\text { torno desse gênero literário. }\end{array}$ & $\begin{array}{l}\text { Capacidades de ação e } \\
\text { discursivas }\end{array}$ \\
\hline
\end{tabular}

PONTES; DUARTE. O ensino dos pretéritos a aprendizes brasileiros de espanhol como língua estrangeira sob $o$ viés da tradução funcionalista

Belas Infiéis, v. 7, n. 1, p. 201-227, 2018. 


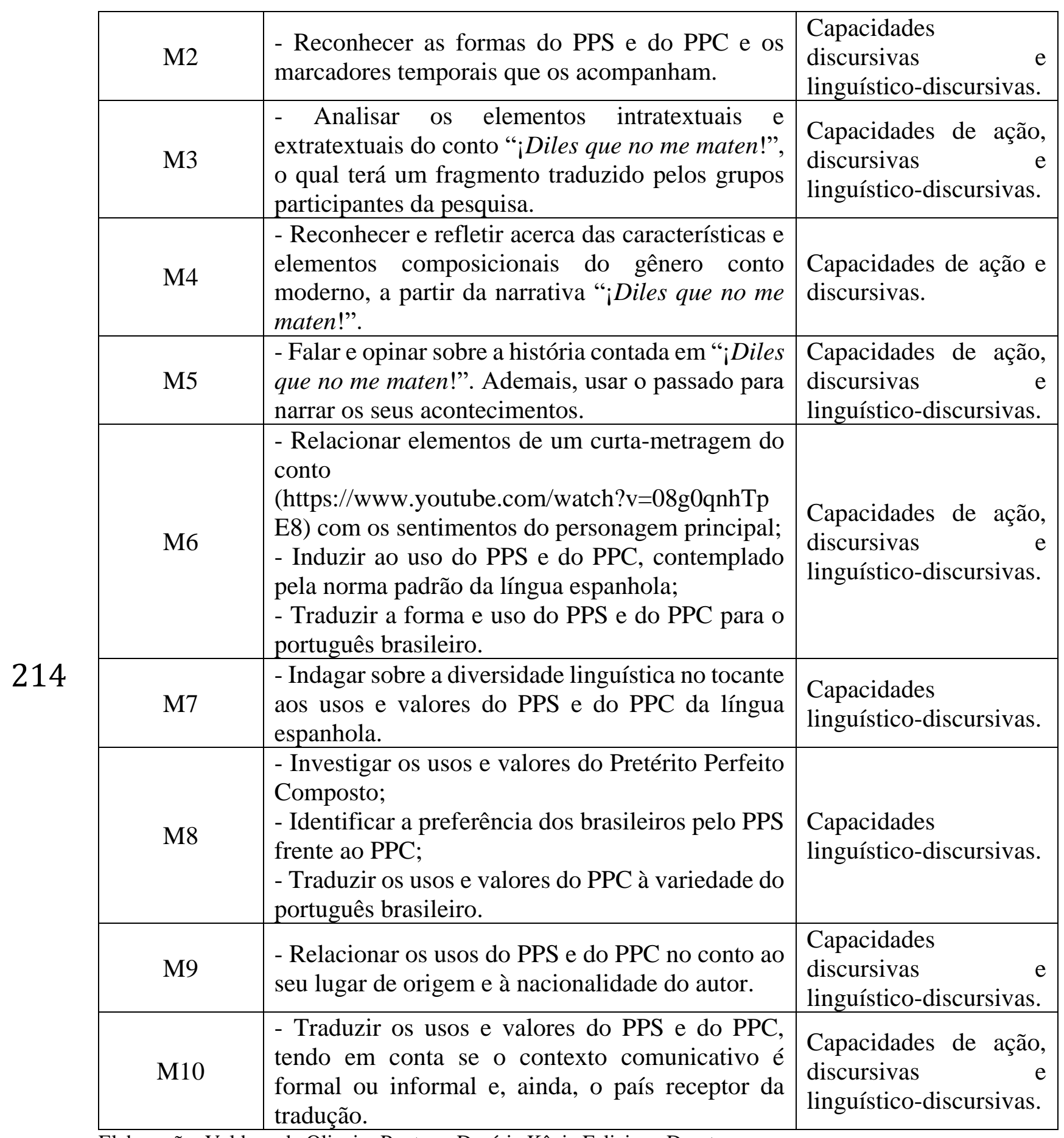

Elaboração: Valdecy de Oliveira Pontes e Denísia Kênia Feliciano Duarte

Os três módulos iniciais foram efetuados antes da primeira produção, o primeiro e o segundo com o intuito de ativar os conhecimentos dos participantes acerca do gênero conto e as suas características e reconhecer a estrutura do Pretérito Perfeito do espanhol (COSTA HÜRBES e SIMIONE (2014)) e terceiro para identificar as dificuldades tradutórias no que tange aos fatores intratextuais e os extratextuais, a partir da análise pré-tradutória de Nord (2012). Tais dificuldades foram confirmadas na Grade de Avaliação Diagnóstica da primeira 
tradução. No quarto módulo, reforçamos a composicionalidade do gênero conto. No quinto, induzimos os grupos a usarem o pretérito perfeito (simples o/e composto), a partir dos seus conhecimentos prévios destes tempos verbais. Do sexto ao décimo módulos, de forma integrada, abordamos o fenômeno de variação linguística nos usos do PPS e do PPC em espanhol, com o propósito de conscientizar os participantes sobre os diferentes usos e valores desses tempos verbais e de suas implicações nas variedades da língua espanhola, além de fazer ponderações sobre o PPS e o PPC no português brasileiro, ao traduzi-los para a sua língua materna. Posto isto, ilustramos a seguir o desenho da versão final da nossa SD:

Figura 1 - Versão final da Sequência Didática.

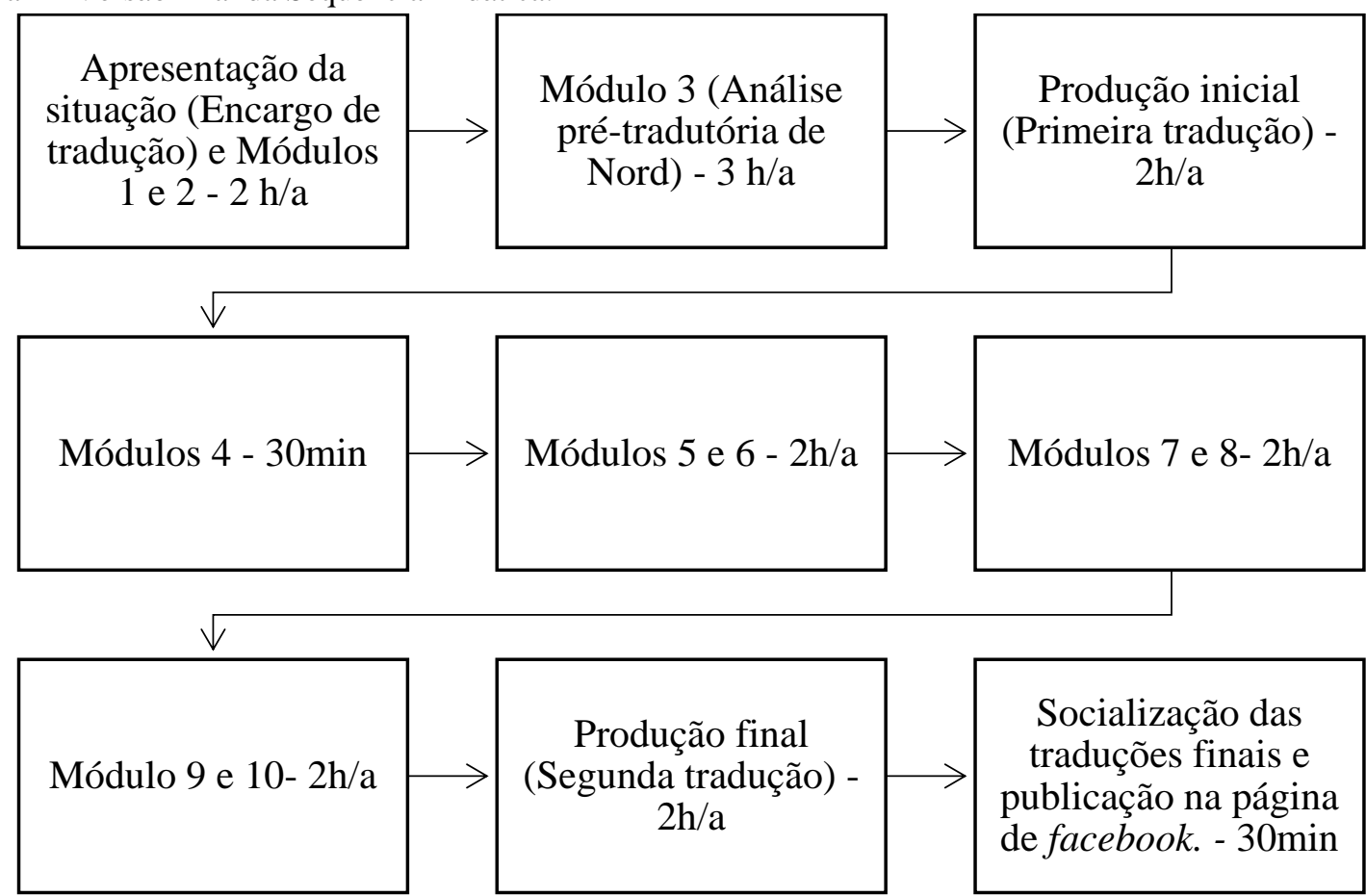

Elaboração: Valdecy de Oliveira Pontes e Denísia Kênia Feliciano Duarte

Corroborando Barros (2012), julgamos que os módulos são cruciais para o desenho da SD, posto que, por meio deles, realizamos atividades com distintos objetivos e graus de dificuldades variados, as quais podem ajudar a melhorar a produção final dos aprendizes. Desta forma, buscamos explorar, nos módulos, tanto questões linguísticas quanto extralinguísticas, tendo em conta que este estudo foca nas diferenças dos usos e valores do PPS e do PPC e a variação linguística no que se refere a esses tempos verbais.

\section{Análise}

PONTES; DUARTE. O ensino dos pretéritos a aprendizes brasileiros de espanhol como língua estrangeira sob o viés da tradução funcionalista

Belas Infiéis, v. 7, n. 1, p. 201-227, 2018. 
Nesta seção, deter-nos-emos na descrição e análise dos dados deste estudo. Foram selecionados trechos das traduções (tradução inicial e final) dos cincos grupos participantes, de acordo com a especificidade de cada contexto de uso do PPS e do PPC no espanhol mexicano e português brasileiro. Em nosso percurso teórico-metodológico, primeiramente, buscamos a compreensão dos usos e valores do Pretérito Perfeito, a partir da tradução funcionalista de um conto pertencente à variedade mexicana, em nível básico $(\mathrm{A} 2)^{8}$ de aprendizagem, visto que o nosso objetivo geral é analisar as contribuições do uso da tradução para o ensino da variação linguística do PPS e do PPC, a estudantes brasileiros de E/LE. Para isto, norteamo-nos pelas seguintes perguntas:

Quadro 5 - Perguntas Norteadoras - Grade de Análise Diagnóstica (GAD).

\section{Perguntas Norteadoras}

1. A tradução está adequada ao português brasileiro?

2. A tradução está adequada às normas gramaticais e à variedade linguística da Língua Meta (português brasileiro)?

216 3. A tradução do Pretérito Perfeito Simples e Composto está adequada à forma e aos usos desses tempos verbais na Língua Meta?

4. A tradução do Pretérito Perfeito Simples e Composto está adequada aos usos e valores desses tempos verbais na Língua Meta, inclusive, aos da variedade brasileira escolhida? Desta forma, os usos do PPS e do PPC variaram de acordo com os condicionamentos linguísticos e extralinguísticos exercidos pela região da variedade linguística analisada?

5. A categoria Modalidade possibilitou expressar o valor de certeza ou incerteza das personagens frente às ações ocorridas? E os valores modais permitiram fazer pressuposições acerca da intenção do falante?

6. Há adaptação da função sintática dos conectivos temporais junto ao PPS e ao PPC, de acordo com a Língua Meta?

7. Os marcadores aspectuais junto ao PPS e ao PPC evidenciam se as ações foram concluídas ou ainda perduram, transparecendo os valores aspectuais de duratividade, dinamicidade e telicidade?

Elaboração: Valdecy de Oliveira Pontes e Denísia Kênia Feliciano Duarte

Vejamos o contraste entre as traduções do primeiro grupo:

PONTES; DUARTE. O ensino dos pretéritos a aprendizes brasileiros de espanhol como língua estrangeira sob $o$ viés da tradução funcionalista

Belas Infiéis, v. 7, n. 1, p. 201-227, 2018. 
Tabela 01 - Contraste - G1 - pergunta $\mathrm{n}^{\circ} 6$ da GAD.

\begin{tabular}{lcl}
\hline \multicolumn{1}{c}{ TEXTO BASE } & $1^{\text {a TRADUÇÃO }}$ & $2^{a}$ TRADUÇÃO \\
\hline "Yo no le he hecho daño a & "Eu não causei dano a "Gente, eu nunca fiz mal a \\
nadie, muchachos" & ninguém, rapazes." & ninguém." \\
\hline
\end{tabular}

Elaboração: Valdecy de Oliveira Pontes e Denísia Kênia Feliciano Duarte

O G1, ao traduzir o PPC, na primeira tradução, cometeu um equívoco no que se refere ao uso deste tempo verbal no português brasileiro, considerando que, na norma padrão da língua espanhola, usa-se o PPC para expressar um evento que se prolonga até o presente e, na língua portuguesa, o PPS pode ter este valor quando acompanhado por adjuntos (MATTE BON 1995b; GUTIÉRREZ ARAUS, 1997; BARBOSA, 2003, etc). Já na segunda tradução, como podemos observar, o G1 traduziu o PPC pelo PPS junto a um adjunto adverbial de tempo (nunca fiz), o que é coerente, de acordo com os estudos de Barbosa (2003, 2008).

Tabela 02 - Contraste - G2 - pergunta $\mathrm{n}^{\circ} 2$ da GAD.

\begin{tabular}{|c|c|c|c|c|}
\hline & XTO BASE & & $1^{\mathrm{a}}$ TRADUÇÃO & $2^{\mathrm{a}}$ TRADUÇÃO \\
\hline $\begin{array}{c}\text { "Con } \\
\text { pasó.", }\end{array}$ & nosotros, & eso & "Isso passou com agente." & "Isso passou com a gente." \\
\hline
\end{tabular}

Elaboração: Valdecy de Oliveira Pontes e Denísia Kênia Feliciano Duarte

Nota-se que o G2, na primeira tradução, cometeu um deslize gramatical ao traduzir o termo "con nosotros" do espanhol pelo substantivo "agente" do português. Entretanto, corrigiu este equívoco na segunda tradução, ao optar pela locução pronominal "a gente", a qual é coerente com a variedade linguística mobilizada. Podemos inferir que durante o ato tradutório os aprendizes aprimoram não só os conhecimentos da LE, mas também os da sua LM, premissa a qual confirmamos através da realização da SD em questão.

Por meio da comparação dos trechos destacados na tabela abaixo, averiguamos que, na $2^{\mathrm{a}}$ tradução (produção final), o G2 adequou a tradução do verbo "decir" no PPS do espanhol, adaptando este verbo, que estava conjugado na primeira pessoa do singular do presente do indicativo do português, na primeira tradução, pela terceira pessoa do singular do PPS do português, na segunda tradução. Também houve adaptação em relação aos elementos composicionais do gênero conto, já que, ao escrever a versão final, o segundo grupo, em vez de

PONTES; DUARTE. O ensino dos pretéritos a aprendizes brasileiros de espanhol como língua estrangeira sob $o$ viés da tradução funcionalista

Belas Infiéis, v. 7, n. 1, p. 201-227, 2018. 
fazer uma tradução literal do termo "eso dijo" - elemento que, nos contos, normalmente, acompanha as falas dos personagens -, como foi feito na primeira tradução, optou por utilizar o termo "ele disse", o que está adequado no que toca às estruturas convencionais do gênero conto na variedade do português brasileiro.

Tabela 03 - Contraste - G2 - pergunta $\mathrm{n}^{\circ} 6$ da GAD.

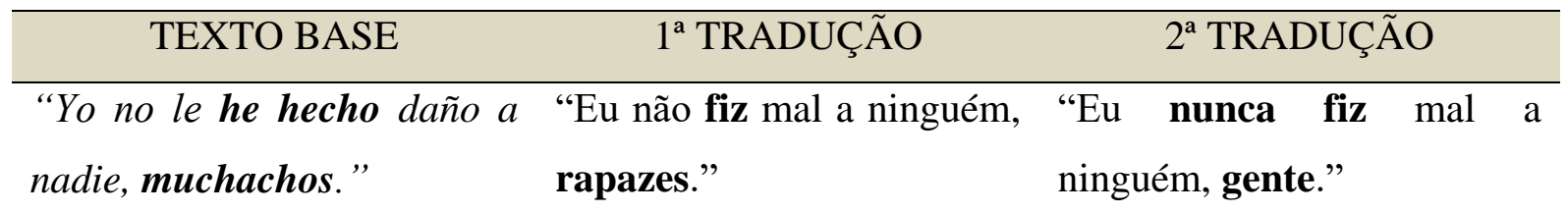

Elaboração: Valdecy de Oliveira Pontes e Denísia Kênia Feliciano Duarte

Na primeira versão do TM, constatamos que o G2 traduziu o PPC do espanhol pelo PPS do português. Já na segunda versão, apesar do PPC do espanhol também ser traduzido pelo PPS do português, ele está acompanhado por um adjunto adverbial de tempo. Ao alterar a tradução do PPC do espanhol para o português brasileiro no contexto comunicativo destacado, a

218 produção final correspondeu ao que nos afirmam os estudos de Barbosa (2003, 2008), isto é: o PPS do português, quando acompanhado de um adjunto, pode expressar valor passado continuativo, valor que foi expresso pelo PPC no TB. Também cabe destacar a mudança na escolha lexical do G2. Como podemos observar, o vocábulo "muchachos", ao ser retextualizado, é traduzido por "gente", em vez de "rapazes". A nosso ver, esta mudança tradutória torna a tradução mais adequada, partindo do pressuposto de que no encargo de tradução ficou delimitado que seria utilizada uma linguagem informal.

No que se refere às mudanças tradutórias do G3, a produção final deste grupo apresentou alterações no tocante à tradução do PPS do espanhol mexicano para o português brasileiro. A saber:

Tabela 04 - Contraste - G3 - pergunta $\mathrm{n}^{\mathrm{o}} 3$ da GAD.

\begin{tabular}{|c|c|c|c|c|c|}
\hline \multicolumn{3}{|c|}{ TEXTO BASE } & $1^{\mathrm{a}}$ TRADUÇÃO & $2^{\mathrm{a}}$ TRADUÇÃO & \\
\hline $\begin{array}{l}\text { "Pero ellos } \\
\text { detuvieron." }\end{array}$ & & & "Todavia eles não o deteram." & $\begin{array}{l}\text { "Mas eles não } \\
\text { detiveram." }\end{array}$ & se \\
\hline
\end{tabular}

Elaboração: Valdecy de Oliveira Pontes e Denísia Kênia Feliciano Duarte

Percebemos, a partir da tabela acima, que o terceiro grupo, na sua primeira tradução, conjuga inadequadamente o verbo "deter", ao utilizar a forma "deteram", a qual é agramatical

PONTES; DUARTE. O ensino dos pretéritos a aprendizes brasileiros de espanhol como língua estrangeira sob $o$ viés da tradução funcionalista

Belas Infiéis, v. 7, n. 1, p. 201-227, 2018. 
na língua portuguesa. Já na segunda tradução, o G3 utiliza a forma "detiveram”, a qual está gramaticalmente correta. Deste modo, corroborando Castro (1996), Concha Moreno e Eres Fernández (2007) e Barbosa (2008), consideramos que, após a resolução dos módulos, o terceiro grupo traduziu o PPS adequando-o à forma e ao uso da Língua Meta, tendo em vista que, no contexto empregado, o PPS é usado para expressar uma ação passada que não tem relação com o presente e que "detiveram" é a forma do verbo "deter" conjugado na terceira pessoa do plural.

Tabela 05 - Contraste - G4 - pergunta $\mathrm{n}^{\circ} 4$ da GAD.

\begin{tabular}{lcl}
\hline \multicolumn{1}{c}{ TEXTO BASE } & $1^{\text {a }}$ TRADUÇÃO & $2^{\text {a TRADUÇÃO }}$ \\
\hline "Yo no le he hecho daño a "Eu não causei dano a "Eu não fiz mal a ninguém, \\
nadie, muchachos" & ninguém, rapazes." & gente." \\
\hline
\end{tabular}

Elaboração: Valdecy de Oliveira Pontes e Denísia Kênia Feliciano Duarte

Nota-se, a partir da tabela acima, que, ao escrever a primeira versão, o G4 opta por uma tradução mais literal, traduzindo "he hecho daño" por "causei dano", o que não é usual na maioria das variedades regionais do português brasileiro. Já na segunda tradução, o G4 realiza algumas mudanças tradutórias no intuito de tornar o seu TM (Texto Meta) mais familiarizado com o público meta, determinado pelo encargo de tradução. Contudo, a versão final do TM do G4 ainda apresenta incoerências, neste caso específico, com relação à tradução do PPC do espanhol. No TB (Texto Base), através dos valores modais expressos pelo PPC, subtende-se que o personagem Juvencio afirma que não fez mal a ninguém e continua sem fazer até o momento do enunciado. Tais valores modais se perdem na primeira e na segunda versão do TM, visto que o G4 traduz o PPC do espanhol pelo PPS do português sem estar acompanhado de um adjunto adverbial de tempo, levando-nos a entender que Juvencio não fez mal a ninguém em um passado distante, entretanto, pode ter feito isto no presente (MATTE BON, 1995a; BARBOSA, 2003, 2008).

Elencadas as dificuldades identificadas no G4, reiteramos a importância de considerar a situação pragmático-discursiva do texto a ser traduzido, partindo do pressuposto de que se, ao traduzir, interpretarmos apenas as estruturais lexicais e morfossintáticas de forma isolada, provavelmente não alcançaremos uma tradução funcional (PONTES, 2014, NORD 1991, 2012). Assim, faz-se necessário analisar os aspectos sociolinguísticos dentro do texto, considerando que estes podem ampliar os conhecimentos acerca do contexto no qual o texto foi

PONTES; DUARTE. O ensino dos pretéritos a aprendizes brasileiros de espanhol como língua estrangeira sob $o$ viés da tradução funcionalista

Belas Infiéis, v. 7, n. 1, p. 201-227, 2018. 
produzido. Retomando Travaglia (2013), salientamos que o tradutor não traduz uma língua, mas textos, nos quais uma intenção comunicativa se organiza sob a forma linguística, por isso vemos a tradução como uma retextualização.

Em relação à versão final do TM de grupo G1, observamos que este realizou algumas modificações com o propósito de adaptar o seu texto ao encargo de tradução mobilizado. Por exemplo, no que tange à tradução dos usos e valores do PPS e do PPC do espanhol e do português brasileiro, verificamos que, na segunda tradução, o G5 corrigiu alguns equívocos cometidos na versão anterior. Vejamos:

Tabela 06 - Contraste - G5 - pergunta $\mathrm{n}^{\circ} 7$ da GAD.

\begin{tabular}{ccc}
\hline TEXTO BASE & $1^{\text {a }}$ TRADUÇÃO & $2^{\text {a }}$ TRADUÇÃO \\
\hline "Siempre tuvo la suerte... & "Eu sempre tive a sorte." & "Sempre teve sorte."
\end{tabular}

Elaboração: Valdecy de Oliveira Pontes e Denísia Kênia Feliciano Duarte

No TB, o verbo "tener/ter" está conjugado no PPS do indicativo, acompanhado pelo marcador temporal hodierno "siempre/sempre", expressando que a ação de ter sorte perdura até o presente do falante. Este mesmo valor é expresso na primeira e na segunda versões do Texto Meta, nas quais o PPS do espanhol foi traduzido pelo PPS do português. No entanto, nota-se um deslize na primeira tradução, já que o verbo "ter" no TB está conjugado na terceira pessoa do singular, e quando é retextualizado no português, está conjugado na primeira pessoa do singular. Tal deslize é corrigido na segunda tradução, tornando-a coerente. Averiguamos que o uso do marcador temporal junto ao verbo facilitou a tradução do PPS, visto que este evidenciou que a ação ainda perdurava até o presente do falante, expressando o valor aspectual de duratividade. Vale destacar que, a partir da tradução do fragmento acima, interpretamos que o G5, durante o ato tradutório, tomou conhecimento sobre a variação linguística relacionada aos usos do Pretérito Perfeito do espanhol, posto que o PPS pode vir acompanhado de um marcador temporal hodierno, o que converge com o estudo de Oliveira (2010). Conforme Barbosa (2003, 2008), na variedade do português brasileiro, as ações passadas que perduram até o momento do enunciado podem ser expressas tanto pelo PPC quanto pelo PPS + adjuntos.

Posto isto, ressaltamos que, apesar do equívoco na produção inicial, no que toca à conjugação do PPS na primeira pessoa do singular em vez de na terceira pessoa do singular, averiguamos que o G5 foi coerente no que se refere à tradução dos usos e valores do PPS do 
espanhol. Entretanto, isso não ocorreu em relação à tradução dos usos e valores do PPC. Vejamos:

Tabela 07 - Contraste - G5 - pergunta $\mathrm{n}^{\circ} 1$ da GAD.

\begin{tabular}{|c|c|c|}
\hline TEXTO BASE & $1^{\text {a }}$ TRADUÇÃO & $2^{\mathrm{a}}$ TRADUÇÃO \\
\hline $\begin{array}{l}\text { "Yo no le he hecho daño a } \\
\text { nadie, muchachos" }\end{array}$ & $\begin{array}{l}\text { "Eu não causei dano a } \\
\text { ninguém, rapazes." }\end{array}$ & $\begin{array}{l}\text { "Gente, eu não fiz } \\
\text { com ninguém." }\end{array}$ \\
\hline
\end{tabular}

Elaboração: Valdecy de Oliveira Pontes e Denísia Kênia Feliciano Duarte

O grupo G5, ao traduzir o PPC, na primeira tradução, cometeu uma inadequação no que diz respeito aos usos e valores deste tempo verbal na língua do Texto Meta. No TB, o PPC expressa uma ação passada que perdura até o presente, isto é, o personagem (Juvencio) expressa, a partir do uso do PPC, que até o momento presente nunca fez mal a ninguém. Ao tentar retextualizar este valor na primeira e na segunda traduções, o G5 comete um engano, pois utiliza o PPS sem estar devidamente acompanhado de um adjunto adverbial de tempo, o que nos conduz a compreender que o personagem supracitado não fez mal a ninguém no passado acabado, onde a ação de fazer mal não é durativa (BARBOSA, 2003, 2008; PEREIRA 2016; BELLO 1979). A nosso ver, apesar de o quinto grupo cometer equívocos quanto à tradução do PPC, há uma evolução entre a versão inicial e a versão final do TM, pois, nesta última, apresenta uma tradução mais adequada ao português brasileiro, visto que não traduz palavra por palavra, mas busca retextualizar, no Texto Meta, um sentido correspondente ao do Texto Base na variedade mobilizada. O grupo segue a perspectiva funcional de Reiss e Vermeer (1996), os quais asseveram que, ao traduzir, não devemos nos limitar a um processo puramente linguístico, pois a tradução também é um processo cultural, considerando que o ato de traduzir é uma ação repleta de intenções e propósitos.

\section{Considerações finais}

Em nossa hipótese inicial, julgávamos que o uso de sequência didática (SD) com a tradução do gênero conto possibilitaria o conhecimento do PPS e do PPC no que toca à diversidade linguística desses tempos verbais, partindo da premissa de que, ao traduzir um texto literário, como em outros gêneros, podemos perceber que muitas são as diferenças de valores entre as culturas. Em nossa análise, averiguamos que de fato houve mudanças no que concerne às traduções do PPS e do PPC entre a primeira e a segunda traduções.

PONTES; DUARTE. O ensino dos pretéritos a aprendizes brasileiros de espanhol como língua estrangeira sob $o$ viés da tradução funcionalista

Belas Infiéis, v. 7, n. 1, p. 201-227, 2018. 
Nas primeiras traduções, geralmente, os grupos participantes traduziam o PPS e o PPC do espanhol pela forma simples do pretérito perfeito do português. Nas traduções finais, identificamos que os grupos perceberam que há diferenças nos usos e valores temporais, aspectuais e modais do PPS e do PPC de acordo com a variedade da língua, ou seja, tomaram conhecimento, por meio da tradução de “iDiles que no me maten!”, que nem sempre os usos desses tempos verbais estão em consonância com o que nos remetem a norma gramatical e que esses podem apresentar valores diferentes, dependendo da cultura de cada lugar.

\section{REFERÊNCIAS BIBLIOGRÁFICAS}

ALCAÍNE, Azucena. 2007. ¿Son compatibles los cambios inducidos por contacto y las tendencias internas al sistema?. Madrid, 18 de julio. Data de consulta, 1 de julio de 2015. http://web.uam.es/personal_pdi/filoyletras/alcaine/Homenaje\%20zimmermann.pdf

\section{ALEZA IZQUIERDO, Milagros e ENGUITA UTRILLA, José María. La lengua española} en América: normas y usos actuales. Valencia. 2010.

BARBOSA, Juliana Bertucci. Os tempos do pretérito no português brasileiro: perfeito simples e perfeito composto. Araquara, SP: UNESP, 2003. Originalmente apresentada como dissertação de mestrado, Universidade Estadual Paulista, 2003.

BARBOSA, Juliana Bertucci. Tenho feito/fiz a tese: uma proposta de caracterização do pretérito perfeito no português. Tese de doutorado, Araquara, SP: UNESP, 2008. Originalmente apresentada como tese de doutorado, Universidade Estadual Paulista, 2008.

\section{BARRIENTOS, B.R.R. Os quadrinhos da Mateina no ensino de espanhol língua} estrangeira: à luz da tradução funcionalista. Dissertação (Mestrado em Estudos da Tradução) - Centro de Comunicação e Expressão. Universidade Federal de Santa Catarina: Florianópolis, 2014.

BARROS, Eliana Merlin Deganutti. Gestos de ensinar e de aprender géneros textuais: a sequência didática como instrumento de avaliação. Londrina, PR: UEL, 2012. Originalmente apresentada como tese de doutorado, Universidade Estadual de Londrina, 2012.

BELLO, Andrés. Análisis ideológico de los tiempos de la conjugación. In: Obra Literaria. Caracas: Ayacucho, 1979, p. 415-459.

BORTONI-RICARDO, Stella Maris. Nós cheguemu na escola, e agora? sociolinguística \& educação. São Paulo: Parábola, 2006.

BRONCKART, J. P. Restrições e liberdades textuais, inserção social e cidadania. Anpoll, 19, p. 231-256, 2001.

CASTRO, Francisco. Uso de la gramática española (elemental). Madrid, Edelsa, 1996.

PONTES; DUARTE. O ensino dos pretéritos a aprendizes brasileiros de espanhol como língua estrangeira sob $o$ viés da tradução funcionalista

Belas Infiéis, v. 7, n. 1, p. 201-227, 2018. 
CONCHA, Moreno; ERES FERNÁNDEZ, Gretel. Gramática contrastiva españolportugués para hablantes brasileños. Madrid: SGEL, 2007.

COSTA-HÜBES, T. C; SIMIONI, C. A. Sequência didática: uma proposta metodológica curricular de trabalho com os gêneros discursivos/textuais. In: BARROS, E. M. D; RIOSREGISTRO, E. S (org.). Experiências com sequências didáticas de gêneros textuais. Campinas, SP: Pontes editores, 2014.

CRISTOVÃO, Vera. "Sequências didáticas para o ensino de línguas”. In: DIAS, R.; Cristovão, V. (Org.). O livro didático de língua estrangeira: múltiplas perspectivas. Campinas: Mercado de Letras, 2010, p. 305-344.

DIAS, Luzia. Schalkoski. Uma leitura semântico-pragmática da oposição Pretérito Simple/Pretérito Compuesto no espanhol da América. Curitiba, PR: UFPR, 2004. Originalmente apresentada como dissertação de mestrado, Universidade Federal do Paraná, 2004.

DOLZ, J.; PASQUIER, A.; BRONCKART, J-P. L'acquisition des discours: emergence d'une compétence ou apprentissage de capacités langagières? Études de Linguistique Appliquée, 102:23-37. 1993.

DOLZ, J.; SCHNEUWLY, B. Genres et progression en expression orale et écrite: éléments de réflexions à propos d'une experience romande. Enjeux, 37/38, 1996, p.49-75.

DOLZ, J.; NOVERRAZ, M; SCHNEUWLY, B. Sequências didáticas para o oral e a escrita: apresentação de um procedimento. In: ROJO, R.; CORDEIRO, G.S. (Trad. e Org.) Gêneros orais e escritos na escola. Mercado de Letras: Campinas, SP, 2004.

DONNI DE MIRANDE, Nélida. El sistema verbal en el español de Argentina: rasgos de unidad y de diferenciación dialectal. Revista de filología hispánica. 72: 655-670. 1992.

DUARTE, Denísia Kênia Feliciano. O ensino dos pretéritos em espanhol para brasileiros a partir de contos: a tradução da variação linguística como estratégia didática. 241p. Dissertação (mestrado) - Universidade Federal do Ceará, Centro de Humanidades, Programa de Pós-Graduação em Estudos da Tradução, Fortaleza, 2017.

ENGEL, Guido I. Pesquisa-ação. Revista Educar, Curitiba. №. 16. Editora da UFPR, 2000.

GIL, Antonio Carlos. Como elaborar projetos de pesquisa. $5^{\text {a }}$ ed. São Paulo: Atlas S.A, 2010

GUTIÉRREZ ARAUS, Maria Luz (org.). Formas temporales del pasado en indicativo. Madrid: Arco/Libros, 1997.

HARRIS, M. 1982. Studies in Romance Verb. London: Croom Helm, 1982.

JARA YUPANQUI, Margarita. El perfecto en el español de Lima: Variación y cambio en situación de contacto linguístico. Peru: Fondo editorial. 2013.

PONTES; DUARTE. O ensino dos pretéritos a aprendizes brasileiros de espanhol como língua estrangeira sob o viés da tradução funcionalista

Belas Infiéis, v. 7, n. 1, p. 201-227, 2018. 
LAIÑO, M. J. A tradução pedagógica como estratégia à produção escrita em LE a partir do gênero publicidade. 2014. Tese (Doutorado em Estudos da Tradução) - Centro de Comunicação e Expressão. Universidade Federal de Santa Catarina: Florianópolis, 2014.

MARCO europeu comum de referência para as línguas: aprendizagem, ensino, avaliação. Porto, Edições ASA, 2001. Disponível em: <http://www.uc.pt/fluc/cl/diplomas/qecr/> Acesso em: 26.01.17.

MATTE BON, Francisco. Gramática comunicativa del español: de la lengua a la idea. Tomo I. Barcelona: Edelsa Disal, 1995a.

MATTE BON, Francisco. Gramática comunicativa del español: de la idea a la lengua. Tomo II. Barcelona: Edelsa Disal, 1995 b.

MAYORAL, Roberto. La traducción de la variación lingüística. Universidad de Granada: Granada, 1998.

NASCIMENTO, Elvira; SAITO, Cláudia. Texto, discurso e gênero. In: SANTOS, A. R.; RITTER, L. C. (Org). O trabalho com a escrita no ensino fundamental. Maringá: EDUEM, p. 11-40, 2005.

224 NORD, Christiane. Text Analysis in Translation: theory, methodology and didactic application of a model of translation-oriented text analysis. Amsterdam; Atlanta: Rodopi, 1991.

NORD, Christiane. Traduciendo funciones. In: Hurtado Albir, A. [ed.]: Estudis sobre la traducció Castelló 1993. Castellón: Universidad Jaume I, p. 97-112. 1994.

NORD, Chistiane. El funcionalismo en la enseñanza de traducción. Mutatis Mutandis. v. 2, n. 2. 2009. p. 209 - 243. Disponível em:

<http://aprendeenlinea.udea.edu.co/revistas/index.php/mutatismutandis/article/view/2397>. Acessado em: 03 mar. 2015.

NORD, Christiane. Texto Base - Texto Meta: Un modelo funcional de análisis pretraslativo. Universitat Jaume I: Servei de Comunicació i Publicacions, 2010.

NORD, Christiane. Texto Base - Texto Meta: Um modelo funcional de análise pretradutório. Traduzido por Cristiane Nord. Castelló de la Plana: Publicacions de la Universitat Jaume I, Espanha, 2012. Título original: Texto Base - Texto Meta: Un modelo funcional de análisis pretraslativo.

OLIVEIRA, Leandra Cristina. Estágio da gramaticalização do pretérito perfeito composto do espanhol escrito de sente capitais hispano-falantes. Florianópolis, SC: UFSC, 2010. Originalmente apresentada como tese de doutorado, Universidade Federal de Santa Catarina, 2010. 
PAIXÃO, F.T. O valor aspectual veiculado ao pretérito perfeito composto do espanhol na variante mexicana. 2011. Dissertação (Mestrado em Letras Neolatinas) - Universidade Federal do Rio de Janeiro, Rio de Janeiro. 2011.

PENNY, Ralph. Variación y cambio en español. Madrid: Gredos. 2004.

PEREIRA, Livya Lea de Oliveira.A tradução de textos teatrais como recurso didático para o ensino da variação linguística no uso das formas de tratamento em espanhol a aprendizes brasileiros. 315p. Dissertação (mestrado) - Universidade Federal do Ceará, Centro de Humanidades, Programa de Pós-Graduação em Estudos da Tradução, Fortaleza, 2016.

PONTES, V. O.; PEREIRA, L.L.O; BRASIL, J.O. Os fatores extralinguísticos no uso do voseo argentino: uma proposta didática a partir da tradução de tiras cômicas. Revista Língua e Letras, v. 17, $\mathrm{n}^{\circ}$ 35, p. 59-80, 2016.

PONTES, Valdecy Oliveira. Abordagem das categorias verbais de tempo, aspecto e modalidade por livros didáticos de língua portuguesa e de língua espanhola: uma análise contrastiva. Fortaleza, CE: Fa7, 2009. Originalmente apresentada como monografia, Faculdade 7 de setembro, 2009.

PONTES, Valdecy Oliveira. A tradução da variação linguística e o ensino de língua estrangeira: da teoria à prática docente. Caderno de Letras da UFF: Dossiê de Tradução, Florianópoles, 48, p. 223-237, 2014.

RABARDEL, Pierre. Les Hommes et les technologies: une approche cognitive des instruments contemporains. Paris: Université de Paris 8, 1995.

REISS, Katharina; Vermeer, Hans. Fundamentos para una Teoría Funcional de la Traducción. Tradução Santa García Reina e Celia Martín de Léon. Edição Akal. 1996.

RULFO, Juan. Diles que no me maten! In: El llano en llamas. Madrid: Editorial Planeta, 2007.

SANTOS, C. F. Variação e mudança linguística dos pretéritos simples e composto, uma perspectiva sociolinguística e discursiva: amostras de Madrid, Cidade do México e Buenos Aires. 259f. 2009. Dissertação (Mestrado em Linguística) - Universidade Federal do Rio de Janeiro, Rio de Janeiro. 2009

TRAVAGLIA, Neuza Gonçalves. Tradução retextualização: a tradução numa perspectiva textual. 2. ed. Uberlândia: EDUFU, 2013.

VIDAL DE BATTINI, Berta. E. El español de la Argentina: Estudio destinado a los maestros de las escuelas primarias. Buenos Aires: Consejo Nacional de Educación. 1964.

\footnotetext{
1 Valdecy de Oliveira Pontes - Professor do Departamento de Letras Estrangeiras e dos Programas de Pósgraduação em Linguística (PPGL) e Estudos da Tradução (POET) da Universidade Federal do Ceará (UFC). Pósdoutor em Estudos da Tradução (2014) pela Universidade Federal de Santa Catarina (UFSC), Doutor (2012) em

PONTES; DUARTE. O ensino dos pretéritos a aprendizes brasileiros de espanhol como língua estrangeira sob o viés da tradução funcionalista

Belas Infiéis, v. 7, n. 1, p. 201-227, 2018.
} 
Linguística pela Universidade Federal do Ceará (UFC) e mestre em Linguística Aplicada (2009) pela Universidade Estadual do Ceará (UECE). Graduado em Letras - Português e Espanhol (2006) pela Universidade Federal do Ceará (UFC). Fortaleza, Ceará, Brasil. Lattes: http://lattes.cnpq.br/0958944549142686 ; Email:valdecy.pontes@ufc.br

${ }^{2}$ Denísia Kênia Feliciano Duarte - Mestre em Estudos da Tradução (2016) pelo Programa de Pós-Graduação em Estudos da Tradução na Universidade Federal do Ceará (POET/UFC). Graduada em Letras-Espanhol (2014) pela mesma universidade. Fortaleza, Santa Ceará, Brasil. Lattes: http://lattes.cnpq.br/164847093352464 ; E-mail: denisiaduarte@gmail.com

${ }^{3}$ Citação original: "comparada con otras situaciones comunicativas, la traslación es específica por el hecho de que hay dos culturas (y lenguas) implicadas." (NORD, 2012, p. 13). Em termos de nomenclatura, consideraremos tradução como translação.

${ }^{4}$ Para a aplicação da nossa SD, seguimos o seguinte percurso teórico-metodológico: 1. Apresentação da Situação de Comunicação, que consiste na contextualização da prática de linguagem a ser empreendida e na exposição de uma motivação para a tradução; 2 . Tradução Inicial, que tem a função diagnóstica acerca do domínio do gênero textual pelos alunos e de seus conhecimentos acerca do PPS e do PPC no espanhol mexicano e no português brasileiro; 3. Realização de Módulos, que se constituem de exercícios, atividades ou oficinas baseadas nas dificuldades apresentadas pelos estudantes na tradução inicial; 4. Tradução Final - a produção final pode ser comparada com a produção inicial, proporcionando ao docente uma avaliação do desenvolvimento real do aluno e uma avaliação formativa (BARROS, 2012, 82).

${ }^{5}$ No que se refere aos níveis iniciais (A1- Iniciação / A2 - Elementar), segundo o Quadro Europeu Comum de Referência para as Línguas (QECR, 2001), a nível global, o estudante A2: É capaz de compreender frases isoladas e expressões frequentes relacionadas com áreas de prioridade imediata (p. ex.: informações pessoais e familiares simples, compras, meio circundante). É capaz de comunicar em tarefas simples e em rotinas que exigem apenas uma troca de informação simples e direta sobre assuntos que lhe são familiares e habituais. Pode descrever de modo simples a sua formação, o meio circundante e, ainda, referir assuntos relacionados com necessidades imediatas. (QECR, 2001, p. 29)

${ }^{6}$ Citação original: "Evidentemente, es difícil encontrar textos auténticos que no sean demasiado largos y que dispongan del grado exacto de dificultad adecuado para los alum-nos de un determinado nivel. Pero si un texto es demasiado largo o demasiado difícil, la tarea puede facilitarse con un encargo específico, pidiendo, por ejem-plo, una traducción solo de ciertas partes del texto, combinada con una lectura superficial o con un resumen en la lengua meta del resto (que es, en efecto, una forma especial de traducción y que puede ser motivada por el encargo)." (NORD, 2012, p. 160)

${ }^{7}$ Considerando o uso de contos e a produção de suas respectivas traduções para o desenvolvimento desta pesquisa, como Dolz e Schneuwly (1996), utilizamos as capacidades de linguagem necessárias para a compreensão e produção de um gênero textual em uma dada situação de comunicação. Desta forma, adotamos a noção de capacidades proposta por Dolz, Pasquier e Bronckart (1993), que as configuram em três planos: a) capacidades de ação; b) capacidades discursivas; e c) capacidades linguístico/discursivas. A primeira refere-se às representações com relação ao meio físico e à interação comunicativa (contexto). A segunda está relacionada com a infraestrutura do texto. Por outra parte, a terceira tem relação com os mecanismos de textualização (as operações de conexão e segmentação, coesão nominal e verbal) e com os mecanismos enunciativos (distribuição de vozes e de expressão de modalizadores, construção de enunciados).

${ }^{8}$ Tomamos como base os níveis de aprendizagem do Marco Comum Europeu de Referência para as Línguas (MCER), documento elaborado por sugestão do Conselho Europeu para nortear o ensino de Línguas na comunidade europeia. Conforme o MCER, o nível A2 é considerado como elementar. Isso significa que alguém é situado neste nível, no que se refere ao âmbito linguístico geral, quando "Tem um repertório linguístico elementar que lhe permite lidar com as situações quotidianas de conteúdo previsível, ainda que, geralmente, necessite de estabelecer um compromisso entre a mensagem e a procura de palavras. É capaz de produzir expressões quotidianas breves de modo a satisfazer necessidades simples de tipo concreto: pormenores pessoais, rotinas quotidianas, desejos e necessidades, pedidos de informação. É capaz de usar padrões frásicos elementares e de comunicar com expressões memorizadas, grupos de poucas palavras e de expressões feitas sobre si e sobre outras pessoas, sobre aquilo que fazem, sobre lugares, bens, etc. Tem um repertório limitado de expressões memorizadas PONTES; DUARTE. O ensino dos pretéritos a aprendizes brasileiros de espanhol como língua estrangeira sob o viés da tradução funcionalista

Belas Infiéis, v. 7, n. 1, p. 201-227, 2018. 
curtas que cobrem situações de sobrevivência previsíveis; rupturas e incompreensões frequentes ocorrem em situações não habituais" (MCER, p. 158).

PONTES; DUARTE. O ensino dos pretéritos a aprendizes brasileiros de espanhol como língua estrangeira sob o viés da tradução funcionalista

Belas Infiéis, v. 7, n. 1, p. 201-227, 2018. 